Politiskajā un diemžēè arī teorētiskajā diskursā latviešu valodā ir ierasts runāt par "vienotību": vienotā informācijas telpa, vienotā vēstures izpratne. Televīzijas lietošanas paradumu analīze liecina, ka nav vienotas publiskās sfēras, tāpat kā nav viena neproblemātiski definēta nacionālā "mēs". Latvijā faktiski pastāvošais plurālisms, kuru turklāt nenosaka piederība pie valodas un kultūras kopienas, ir pretrunā ar sabiedriskā medija kā visaptverošas publiskās sfēras koncepciju. Un - uzsver J. Juzefovičs plurālisms nenozīmē solidaritātes mazināšanos. Politikas veidotājiem būtu jāapzinās, ka starp medijiem latviešu un krievu valodā ir vairāki saskarsmes punkti, kas nel̦auj runāt par "paralēlajām informācijas telpām”. Tāpēc publiskā komunikācija var notikt (un tā jau notiek) arī pāri atsevišksiem medijiem un valodām.

Lielu uzmanību J. Juzefovičs pievērš populārajai kultūrai: Eirovīzijas konkursa un sporta spẹ̣̄u translācijām, Jaungada vakara programmām. Arī citi pētnieki Latvijā empīiski parādījuši šo pasākumu integrējošo funkciju. J. Juzefoviča sarunas ar respondentiem lieku reizi apliecina televīzijas potenciālu radīt kopības sajūtu. Pētnieks gan brīdina: nav obligāti, ka šī sajūta radītu nacionālo "mēs", kas būtu pieņemams visiem nācijas locekḷiem. Tomēr iedomātās kopienas teorētiķi nemaz neapgalvo, ka harmoniska vienotība būtu tās obligātais rezultāts.

Grāmatā autors neskar jautājumu par praksēm, kas ir uz J. Hābermāsa publiskās sfēras konceptu balstītās sabiedriskās televīzijas uzmanības centrā. Proti, publiskā sfēra ir vieta, kur indivīdi var spriest par savām privātajām interesēm kā pilsoņi, lai meklētu saskaņu ar līdzpilsoniem un ietekmētu lēmējvaras darbu. Respondentu apgalvojumi, ka vini neatpazīst sevi sabiedriskās televīzijas raidījumos, faktiski varētu liecināt par šo praktiskās dzīves aspektu. Proti, LTV paustā nācijas koncepcija ir reducēta uz J. Hābermasa kultūras publisko sfēru, kuras mērḳis ir latviešu etniskās un profesionālās kultūras saglabāšana, taču ne ikdienas "egoistiskās" ekonomiskās un sociālās dzīves aspektu apspriešana.

Latvijas iedzīvotājus kritizē par nespēju paskatīties pāri savai sētai. Faktiski no J. Juzefoviča informantu sacītā var secināt: viņus neapmierina tas, ka viņiem piedāvā tikai kultūras publisko sfēru, atstājot novārtā politisko, kurā viņi varētu runāt par savām "savtīgām" atšķirībām, meklējot kopību ar citiem.

\title{
PĒTĪJUMĀ MEKLĒTAS ATBILDES
}

\author{
Guntis Zemītis, Dr. hist., Biznesa augstskolas Turība profesors, \\ LU Latvijas vēstures institūta direktors
}

Objektīvas recenzijas ir anonīmas. Publicēta recenzija vienlaicīgi kḷūst par recenzenta publikāciju. Tāpēc publicētā recenzijā gribot negribot mēdz izpausties recenzenta subjektīvisms, aiz kura reizēm pazūd pats recenzijas objekts. Šì recenzija noteikti nevar pretendēt uz pilnīgu objektivitāti - Andris Pētersons ir recenzentam labi pazīstams, recenzents rakstījis šīs viṇa monogrāfijas ([2017] Latvijas iedzīvotāju atvērtība starpkultūru komunikācijai. Rīga : Biznesa augstskola Turība) priekšvārdu un pat minēts kā tās konsultants. Un tomēr - monogrāfija neapšaubāmi ir A. Pētersona autora darbs. Viņš vienīgais ir interpretējis pētijuma rezultātus un pasniedz tos savā monogrāfijā. Tas, ka recenzents ir pazīstams ar A. Pētersona agrākajiem darbiem, viṇa rakstīšanas stilu, pat darba stilu un domāšanas veidu, ne tikai netraucē, bet arī palīdz labāk izprast viņa ieceres, materiālu atlases veidu un secinājumu būtību.

Pētījums, kuru veica Biznesa augstskolas Turība studenti A. Pētersona vadībā par Latvijas iedzīvotāju (domāti visi pastāvīgie 
iedzīvotāji, ne tikai pilsoņi) atvērtību starpkultūru komunikācijai, tapa 2015. gadā, laikā, kad Eiropu pārpludināja musulmaņu bēgḷi. Ik pa brīdim notika kāds asiņains terora akts, pienāca ziṇas par sieviešu "apgrābstīšanu", reizēm arī izvarošanu un slepkavībām. Atvērtā, iecietīgā Eiropa bija nonākusi ja ne gluži krīzē, tad pamatīgā apjukumā gan. Ko darīt tālāk? Atteikties no pēckara gados izkoptajām un iesakņotajām vērtībām un atgriezties pie neiecietības? Griezt bēgḷ laivas atpakal vai pat šaut uz tām? Diskusijas uzvirmoja arī Latvijā, kuru gan bēgḷu krīze tā īsti neskāra. Jautājums bija tikai par to, vai mūsu valsts teorētiski piekritīs uzņemt kaut dažus bēgḷus. Bēgḷu krīze varbūt deva stimulu pētījumam, bet tas noteikti nav par bēgliem un gatavību tos uznemt.

Uzreiz jānorāda, ka pētījums par Latvijas sabiedrības atvērtību ir loti aktuāls un nepieciešams. Pētījuma laikā aptaujāts 1001 respondents, aptverti visi Latvijas kultūrvēsturiskie apgabali. Respondenti izvēlēti tā, lai to skaits atbilstu Latvijas iedzīvotāju etniskā sadalījuma modelim, pēc kura latvieši veido $61,6 \%$, krievi 25,8\%, baltkrievi 3,4\% utt. (2015. gada dati).

Pētījuma aktualitāti nosaka arī tas, ka Latviju, lai gan tā sevi postulē kā nacionālu valsti, bieži uztver kā divkopienu valsti, kāda tā veidojās padomju okupācijas gados. Šāds dalījums ir mākslīgs, netaisnīgs, tomēr tā izpausmes ir jūtamas. Netaisnīgs tas ir gan tāpēc, ka tas veidojās kā padomju okupācijas sekas, gan arī tāpēc, ka tas saglabā padomju sabiedrības modeli, kas neredz mazākumtautības, iekḷaujot tās vienotā "krievvalodīgo" masā. Pētījumā mazākumtautību viedoklis n,emts vērā, un tas ir apsveicami. Nav šaubu, ka realitātē joprojām vērojamas atškirības starp latviski runājošo vairākumu un krieviski runājošo mazākumu. Cēloṇi meklējami vēsturē, kam pieskaras arī A. Pētersons. Tomēr, kas notiek ārpus ikdienā redzamā, - tas, ka mēs atškirīgi balsojam vēlēšanās, atšksirīgi vērtējam Krievijas ārpolitiskās aktivitātes, attiecīgi atškirīgi uzskatām to par draugu vai draudu, tas līdz šim palicis neizvērtēts. Vai mums ir atšķirīgi uzskati par vērtībām, laimi, ğimeni, veselību? Un kuri, beigu beigās, ir neiecietīgāki pret iebraucējiem - tradicionāli par noslēgtiem un nacionālistiski noskaņotiem uzskatītie latvieši vai krievi, kuriem padomju propaganda piedēvēja izteiktu internacionālismu un atvērtību? Īsāk sakot - trūkst pētījumu par to, kādi esam, kas mums ir kopīgs un kas atškikirīgs. Trūkst pētījumu par to, kā mēs rīkosimies situācijā, kas vienādi skar visus Latvijas iedzīvotājus. Vienoti vai atšķirīgi. Līdz ar to nav šaubu, ka gan pats pētījums, gan A. Pētersona monogrāfija, kas analizē pētījuma rezultātus, ir vietā un laikā.

Pētījumā meklētas atbildes uz trim jautājumiem: cik atvērti starpkultūru komunikācijai ir Latvijas iedzīvotāji, kādas vērtības ir noz̄imīgas Latvijas iedzīvotājiem, kādas individuālās un kolektīiās vērtības spēja apdraudēt imigrantu pieplūdums Latvijā?

A. Pētersons ir uzmanīgs lasītājs un klausītājs. Viņš brīvi orientējas l̦oti plašā literatūras klāstā, pārzina gan pagātnes domātāju, gan mūsdienu filozofu, psihologu, bet galvenokārt komunikācijas speciālistu darbus. Savas domas pamatošanai viňš izmanto daudzus citātus. $\mathrm{Pa}$ derīgai domai viņš atrod gan tajā, ko rakstījis Latviešu Indrikisis 12./13. gadsimtu mijā un 18. gadsimta domātājs Šarls Luijs de Monteskjē, kā arī mūsdienu komunikācijas guru, gan tajā, ko sacījis krievu mafijas sāgas varonis ar iesauku Vācietis no filmas Brālis. Jūtama arī paša dzīves pieredze, kuru viņš lieliski parādījis savos agrākajos darbos (piem.: [2008] Pieskārieni. Kā klūt par savējo starp svešiniekiem un kolègiem. Rīga : Biznesa augstskola Turība; [2012] Ievārījums un brīnumi. Rīga : Atēna), rakstot gan zinātniski, gan savā iemīl’otajā īsās prozas stilā. Jo bagātāks lietojamo paņēmienu arsenāls ir autora rīcībā, jo lielāka viņa meistarība. Bet, kā zināms, meistarībā var arī sapīties. Reizēm tas arī gadās.

Grāmatas ievads sākas ar autora filozofisko, viṇa dzīves pieredzi apliecinošo atziṇu, ka "cilvēks var nodzīvot garu un laimīgu mūžu noslēgtībā, un cilvēks var dz̄ivot ilgi, laimīgi un atvērti kopā ar citiem. Abas šīs iespējas ir vērā ņemamas, jo mēs esam tik dažādi” (9. lpp.). Un tūlīt arī, atsaucoties uz LU profesoru Augustu Miltu, skaidro, kas ir komunikācija, un meklē atbildi uz jautājumu, kādēl cilvēki vēlas saskarties ar citiem cilvēkiem, turklāt pat l’oti apgalvojošā formā. Uz jautājumu "Kāpēc mēs tik loti vēlamies saskarties ar citiem cilvēkiem?" atbildot, ka "cilvēks ir sabiedriska būtne, tāpēc tai nepieciešams būt saskarsmē ar citiem cilvēkiem" (10. lpp.), tādējādi 
nosvītrojot vienu no divām paša sniegtajām atzin̄ām, ka cilvēks tikpat mierīgi un laimīgi var mūžu aizvadīt noslēgtībā. Šeit autors tiešām nedaudz sapinies, nonākot pretrunā pats ar sevi, toties pamatojums, kādēḷ pētījumā tik liela uzmanība pievērsta vērtībām, ir izdevies un tālākais jau log̣iski argumentēts.

Darba pirmajā nodaḷā autors aplūko vērtības un to lomu cilvēka dzīvē. Un sāk to ar Gerta Hofštēdes (Geert Hofstede) sīpolveida sabiedrības modeli, kura kodolu veido vērtības, kas nosaka visu pārējo. Autors atzīst, ka "vērtību lauks ir plašs un uzskatu par to ir tikpat daudz, cik domātāju" (13. lpp.).

Nākamajās divās nodaḷās aplūkota vērtību maiņa pasaulē un Latvijā, pieskaroties arī padomju okupācijas gadiem, kas mainīja sabiedrību un vērtības. Ši tēma ir atsevišksa pētījuma vērta. Neapšaubāmi, l̦oti vajadzīga pētījuma. Autors pieskaras padomju uzspiestajam kolektīvismam. Tomēr ne tik, cik šis fenomens būtu pelnījis. Tas nav pārmetums autoram detalizēta šì jautājuma pētniecība šajā darbā neglābjami vestu prom no tēmas. Lai tas paliek nākamajiem pētījumiem.

Tomēr, ja reiz autors sācis runāt par Latvijas iedzīvotāju vērtību transformāciju, tad vajadzēja dažos teikumos pieskarties tādai vērtībai kā ǵimene. Kā rāda pētîjums, ǵimene mūsdienu Latvijas sabiedrībā tiek vērtēta pārsteidzoši augstu. G̣imene kā vērtība, ko daudzās valstīs tradicionāli ierindo pirmajā vietā, - šeit nekāda brīnuma nav. Tomēr ir jautājums, ko īsti saprotam ar ǵimeni kā vērtību. Un šeit atskats uz padomju laiku ir nepieciešams. Vārdos ǵimene padomju laikā tika definēta kā "sabiedrības pamatšūniņa”, tomēr praksē tās nozīme bija niecīga. Laika gaitā gan daudzas padomju dogmas neizturēja laika pārbaudi un tika atmestas, tuvinot izpratni par ǵimeni tai, kāda tā bija Rietumu sabiedrībā. Un tomēr - padomju sistēma jēdzienu "ǵimene" bija ja ne gluži izkropḷojusi, tad traumējusi gan. Padomju varas rītausmā gimene vispār tika uzskatīta par buržuāziskās sabiedrības palieku, kurā sieviete tiek apspiesta un ekspluatēta. Sievietes emancipācija sajaukumā ar padomju kolektīvismu radīja bērnunamu un specskolu baiso sistēmu, kuras sekas izjūtam vēl pašlaik. Atcerēsimies padomju ideologiijas radīto mītisko stāstu par Pavḷiku Marozovu - zēnu, kurš idejas vārdā nodod tēvu. Tas ir pilnīgā pretrunā kristīgajām vērtībām (ceturtais bauslis - "tev būs savu tēvu un māti godāt"), uz kurām gadsimtiem balstījās gimene Rietumu civilizācijā. Vēl 20. gs. 60. gados "biedru tiesas" darba kolektīvos izskatīja jautājumus, kas daudzos gadījums dziḷi skāra cilvēku personīgo dzīvi, l̦aujot darbabiedriem, bet īstenībā Komunistiskās partijas funkcionāriem jaukties cilvēku personīgajā dzīvē un gímenes lietās. Sava nozīme bija tam, ka Padomju Savienībā līdz pat tās sabrukumam vīriešus par homoseksuālām attiecībām krimināli sodīja. Līdz ar to jēdziens "tradicionālā ǵimene", kuru tik bieži dzird lietojam mūsdienās, īstenībā neko nepasaka par g̣imenes vērtībām, tikai vēršas pret iespēju legalizēt tādu gimeni, kuru veidotu viena dzimuma personas.

Ir daudzas lietas, kuras negatīvi ietekmē mūsu sabiedrību, - dzīšanās pēc naudas un ar to saistītā korupcija. Mūsu sabiedrība ar ievērojamu pārsvaru vēl joprojām augstāk vērtē labklājību nekā morāli, jāa, tas šķietami ir raksturīgi kapitālismam, un tomēr pētījuma vērts ir jautājums par to, cik l,oti šo nobīdi vērtību skalā sekmējuši padomju okupācijas gadi. Katrā zin̄ā padomju gadu mākslā dažas parādības ir lieliski dokumentētas - atcerēsimies kaut vai latviešiem tik mīḷo filmu Limuzīns Jāņu nakts krāsā, kurā režisors Jānis Streičs ǵeniāli parāda, kā rodas alkatība. Šì atkal būtu atsevišksa tēma, tomēr, ja padomju kolektīvisma dziḷāka analīze šajā pētîjumā būtu lieka, tad ǵimene kā vērtība prasītu izvērstāku skaidrojumu arī šeit. Katrā zin̄ā recenzijas autoram un, domājams, ne viņam vien šķiet, ka A. Pētersona viedoklī būtu vērts ieklausīties.

Autors aplūkojis arī Latvijas iedzīvotāju etniskās struktūras izmainas. Vērtības, kuras respondentiem piedāvāja sarindot prioritārā kārtībā, tika izraudzītas koleg̣iāli, fokusgrupas diskusijas rezultātā. Nebūtu lietderīgi šeit pārstāstīt galvenās atziņas. Tās ir respondentu atziņas, monogrāfijas autors tās tikai atspoguḷo un analizē. Tomēr ir dažas lietas, kas varbūt nepārsteidza, bet lika aizdomāties gan. Kā jau minēju, visas vecuma grupas kā galveno vērtību minēja ǵimeni. Tieši tāpēc no autora varēja gaidīt dziḷāku šì jēdziena analīzi. Neparasti zemu, tikai 8 . vietā, visu vecumu grupu pārstāvji ierindoja nacionālo identitāti. Ar citiem 
pētījumiem saskan, ka godīgums atpaliek no pārticības, tomēr priecē, ka visjaunākajā grupā (18-24 gadi) tas ierindojas 6. vietā, kamēr divās pēdējās (45-54 un 55-74 gadi) - 7. vietā. Savukārt darbs jaunākajai grupai škiet ievērojami mazsvarīgāks (5. vieta) nekā vinuu vecākiem un vecvecākiem (3. vieta).

Autors veltījis uzmanību arī valodai kā nācijas un nacionālas valsts vērtībai (6. nodal̦a), lai gan aptaujā valoda kā vērtība netika izcelta. Iespējams, ka tā patvērusies jautājumā par nacionālo identitāti, jo valoda nešaubīgi ir viens no nacionālās identitātes stūrakmeniem. Autors labi izprot starpību starp etnisko latvieti un latvieti pēc pilsoniskās piederības. Jautājums l,oti nozīmīgs ne tikai mums, bet visai postpadomju telpai. Iespējams, tas pietrūcis pētījumā - nav šaubu, ka postpadomju telpā etniskā identitāte dominē pār pilsonisko. Tomēr - cik lielā mērā? Vai ir kādas atškirīibas vecuma grupās? Iespējams, ka domāt pilsoniskās kategorijās traucē arī latviešu valodas izteiksme. Proti, krievu valodā ir divi jēdzieni latiš (etniskā nozīmē) un latvijec (pilsoniskā nozīmē), kamēr latviešu valodā ir tikai viens vārds "latvietis", kuru pat pašiem latviešiem grūti lietot pilsoniskā nozīmē. Lìdzīgi gan ir arī, piem., vācu valodā, bet tur pilsoniskā nozīme ar laiku ir iegājusies.

Autors aplūko arī kristīgās vērtîbas un latvisko dzīvesziṇu. Abas tās līdz ar vispārcilvēciskajām vērtībām iekḷautas Latvijas Republikas Satversmes ievadā. Piesakot šo tēmu, A. Pētersons latinu uzstāda augstu - izpratne par to, kas īsti ietilpst jēdzienos "kristīgās vērtības" un "latviskā dzīvesziņa", var būt l,oti dažāda. Pat laikā, kad Satversmes ievads vēl tikai tika rakstīts, diskusijas vairāk bija par to, vai tāda papildu preambula ir vai nav vajadzīga, nekā par tās saturu. Par minēto vērtību saturu - vēl jo mazāk. Izklausās labi, skan eiropeiski un vienlaikus arī nacionāli. To, ka par saturu nav īstas skaidrības, A. Pētersons ir pamanījis, citējot žurnālistu Māri Zanderu, ka, iekḷaujot savā retorikā jēdzienus, kurus nevar izskaidrot, valsts amatpersonas "uzprasās uz nepatikšanām”. A. Pētersons skatās uz abām vērtīibām vēsturiski, atsaucas uz Indrik̦a Livonijas hroniku un arī Atskaņu hroniku, kur abas šīs vērtības aplūkotas kā savstarpēji noliedzošas. Autors gan pamatoti norāda, ka paši kristieši, pie kuriem piederēja abu hroniku autori, nemitīgi atkāpās no viṇu sludinātajām vērtībām - ar Dieva vārdu uz lūpām tiek slepkavots, liekot "zemei mirkt pagānu asinīm", pastrādāti varas darbi pret ticības brāliem, savas nodevas maksātas arī alkatībai. Tomēr atkāpes un izkropḷojumi pašu ideju nemaina. Pēc piecdesmit okupācijas gadiem, kas pavadīti valstī, kurā kristietība tika nīdēta, izpratne par to, kas īsti ir šîs vērtības, ir zudusi, laikam jau nebūs pārspīlējums - sabiedrības lielākajai daḷai. Ko ar tām saprot pats A. Pētersons, īsti pateikts tomēr netiek - vien tas, ka viņš uzskata par vajadzīgu citēt kardinālu Julijanu Vaivodu, ka kristīgās kultūras pamatvērtības ir ticība, cerība un mīlestība. Arī uzticība laulībā, atsacīšanās no vardarbības, grēku piedošana.

Sekošana kristīgajām vērtībām noteikti nav tieši saistāma ar kristietības praktizēšanu. Autors min tirgus un sabiedriskās domas pētījuma centra SKDS pētījuma rezultātus, ka mūsdienu Latvijā $60 \%$ cilvēku Bībeli vispār nelasa, - cilvēks var ievērot šīs vērtības, jo ir tā audzināts, vai uztver tās kā pašas par sevi saprotamas. Iespējams, pat nenodala no latviskās dzīveszinias, par kuras saturu monogrāfijā neko neatrodam. Autors arī nenodala, kuras vērtības pieskaitāmas pie kristīgajām, kuras pie latviskajām. Var gan pieņemt, ka ar "latviskām vērtībām" varētu būt saprasts par tādu tradicionāli uzskatītais darbs un nacionālā identitāte, kamēr kristīgās ietvertas jēdzienā "reliǵija", kas gan nivelē pēdējās līdz formālai piederībai kristietībai un kā vienīgo izpausmi saglabā Bībeles lasīšanu.

Nodalias par vērtībām raisa diskusijas vai šķiet pārāk virspusējas, vairāk konstatējošas, turpretim nodaḷas par atvērtību kā progresa priekšnosacījumu ir uzrakstītas pārliecinoši un šaubas neizraisa. Arī galvenais secinājums, ka sabiedrība ir atvērtāka, nekā tas līdz šim izskanējis plašsaziņas medijos, nezin kāpēc nepārsteidz. Tāpat kā nepārsteidz tas, ka latviešu un cittautiešu atvērtības indekss būtiski neatškiras. Katrā ziṇā visām lielākajām Latvijā dzīvojošajām tautībām fiziskās atvērtības indekss izrādījies augstāks par mentālo. Tas nozīmē, ka praksē mums nav iebildumu dz̄ivot un strādāt kopā ar citu tautību, citas relig̣ijas vai rases pārstāvjiem. Vēl viens būtisks secinājums: mūsu 
valsts sabiedrība ir aizspriedumaina simbolu līmenī - mums vieglāk ielaist svešinieku savā gulamistabā, grūtāk uzticēt kādu no nacionālās identitātes simboliem, teiksim - nest dziesmusvētku karogu, kā tas bija jautāts pētījumā. Viena lieta ir to nojaust, pavisam cita - pierādīt. Biznesa augstskolas Turība veiktais pētījums to ir pierādījis, A. Pētersons savā monogrāfijā zinātniski pamatojis.

Monogrāfija vairs nav nopērkama - tā pieejama vien bibliotēkās. Darbs tomēr pelnījis, lai ar to iepazītos plašāks lasītāju pulks. Gan jau profesors A. Pētersons un, nešaubos, arī vēl kāds no mācībspēkiem to izmanto mācību procesā. Laikā, kad grāmatas lasa arvien mazāk, tas nozīmē, ka grāmatai ir l,oti paveicies - tā dzīvo. Gribētos cerēt, ka arī šīs pārdomas par A. Pētersona monogrāfiju rosinās viṇu padomāt par dažām lietām un tās tiks ja ne uzrakstītas, tad pārspriestas ar studentiem.

Nobeigumā vēl pārdomas, kuras raisīja šogad notikušais Latvijas vēsturnieku 2. kongress. Kongresā piedalījās un uzstājās gan A. Pētersons, gan šo rindu autors. Diskusijās tika skarts jautājums par latviešu vēsturnieku monogrāfijām, kurās dominē germāṇu jeb vācu skola - smaga valoda, rūpiga argumentācija, neskaitāmas atsauces uz citu autoru darbiem. Šādas monogrāfijas tikpat kā nav iespējams tulkot ang̣̣u valodā, kurā pieņemts viegls esejisks rakstīšanas stils. A. Pētersona monogrāfija nav pētījums vēsturē, tomēr vēstures tur ir daudz. Varētu atzīmēt, ka tas, kā raksta šis autors, ir vidusceḷ̌s starp abām skolām - anglosakšu un germāṇu. Varbūt viņam izdodas atrast ceḷu, kā apvienot labāko no abām skolām, to arī novēlu.

\section{CILVĒKS AR VALIDITĀTI}

Ilva Skulte, Dr. philol., Rīgas Stradiņa universitātes asociētā profesore

Viens no Latvijas mediju politikas nesenajiem veidotājiem, tagad partijas Progresīvie līderis Roberts Putnis publicējis grāmatu ES esmu starp jums: Cilvēks ar invaliditāti un sabiedriskie mediji ([2017] Rīga : Vesta-LK), kas ne tikai parāda vina kompetenci mediju, sabiedrības un demokrātijas laukā, bet ir arī sava veida vērtību deklarācija. Tajā viņš detalizēti pievēršas sabiedriskajiem medijiem kā instrumentam cilvēku ar invaliditāti dziḷākam akceptam un integrācijai sabiedrībā. Nelielās grāmatiņas izdevēji lakoniski, bet niansēti risinājuši vāka dizaina jautājumu (mākslinieks Dmitrijs Markovs). Aiz melnbaltās lapas stilizētajiem "uzplēsumiem" vīd daudzkrāsainība, un šie vizuālie elementi ne tikai uzrunā redzi, bet arī liek mobilizēt taustes uztveri un apzināties, cik maz, ja neesi īpaši apguvis, varētu turēt līdzi, piem., Braila lasītājam.
Diemžēl ne viss izdevies vienlīdz labi. Jau grāmatas nosaukums par tā saturu nepasaka gandrīz neko, tiesa, apakšvirsraksts paskaidro, bet arī tas būtu veiksmīgāks, ja dotu mājienu par jautājuma nostādni, nevis savestu kopā divus jēdzienus (kurus cilvēki dzirdējuši pietiekami, lai tie neraisītu interesi, pat ja izpratnes par tiem lielākajā daḷā sabiedrības principā nav). Līdzīgi varētu aprakstīt arī grāmatas saturu.

Nevar noliegt, ka tā rakstīta par sociāli svarīgu, Latvijas mediju politikā aktuālu un vienlaicīgi filozofiski interesantu un nebūt ne vienkāršu tēmu. Turklāt rakstīta ar zināšanām, misijas apzinu un apzinoties rakstītā vērtìbu un nozīmi. Apsveicami arī, ka vairākās grāmatas daḷās izklāstītās domas, idejas un teorētiskie modeḷi ir pietiekami saturiski izvērsti un dzilii, lai latviski izdoto grāmatu klāstā aizpildītu 